\title{
Loïc Artiaga, Balzac et l'Index (1841-1864)
}

\section{Marco Stupazzoni}

\section{(2) OpenEdition}

\section{Journals}

\section{Edizione digitale}

URL: https://journals.openedition.org/studifrancesi/3143

DOI: $10.4000 /$ studifrancesi.3143

ISSN: 2421-5856

\section{Editore}

Rosenberg \& Sellier

\section{Edizione cartacea}

Data di pubblicazione: 1 juillet 2013

Paginazione: 471

ISSN: 0039-2944

\section{Notizia bibliografica digitale}

Marco Stupazzoni, «Loïc Artiaga, Balzac et I'Index (1847-1864)», Studi Francesi [Online], 170 (LVII | II) |

2013, online dal 30 novembre 2015, consultato il 02 février 2023. URL: http://

journals.openedition.org/studifrancesi/3143; DOI: https://doi.org/10.4000/studifrancesi.3143

\section{Questo documento è stato generato automaticamente il 2 février 2023.}

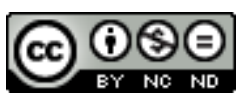

Creative Commons - Attribuzione - Non commerciale - Non opere derivate 4.0 Internazionale - CC BYNC-ND 4.0

https://creativecommons.org/licenses/by-nc-nd/4.0/ 
Loïc Artiaga, Balzac et l'Index (1841-1864)

Marco Stupazzoni 


\section{NOTIZIA}

LOÏC ARTIAGA, Balzac et l'Index (1841-1864), «Mélanges de l'École française de Rome. Italie et Méditerranée», 121-2, 2009, pp. 413-426.

1 Il presente studio costituisce un tassello importante dell'ampia sezione che forma il secondo fascicolo della silloge, dedicata interamente alle relazioni tra letteratura e censura nel XIX secolo. Esso riprende, rivisto e aggiornato, il testo del saggio che L. Artiaga ha dedicato, nel n. 127 ( $1^{\text {er }}$ trimestre 2005) di «Romantisme» all'esame dei rapporti tra l'opera di Balzac e i decreti di condanna all'Index librorum prohibitorum promulgati dalla Sacra Congregazione dell'Indice tra il 1841 e il 1864.

2 L'A. fornisce con equilibrio e competenza il quadro tematico ed ideologico delle osservazioni (i pareri) formulate dai varî consultori a proposito dei testi balzachiani esaminati: sono censurati i riferimenti balzachiani alla filosofia di Swedenborg e al magnetismo animale, l'abuso del lessico religioso riferito a personaggi e a situazioni immorali, il disprezzo dell'autorità e dei ministeri ecclesiastici, l'esaltazione dell'elemento criminogeno della società. La profonda distanza culturale che separa l'Index e l'universo romanzesco balzachiano determina un approccio diretto e deciso dei censori nei confronti dei testi presi in esame e riflette, in tal modo, l'opposizione netta tra due mondi tra loro antitetici: quello proprio della curia romana e quello del romanzo "tout court".

3 In appendice vengono riportate integralmente le citazioni di quei passi contenuti nel Lys dans la vallée ritenuti dal canonico Pio Bighi degni di censura e che sono trascritti nella sua relazione di richiesta di condanna del romanzo all'Indice dei libri proibiti (Decr. del 16 settembre 1841). 